\title{
SZOCIÁLIS ALAPSZÜKSÉGLETEK MÉRÉSE MAGYARORSZÁG RURÁLIS KISTÉRSÉGEIBEN
}

\author{
(A Survey of the Basic Social Needs in Rural Subregions \\ in Hungary)
}

\section{PEISSER-PULI EDIT}

\section{Kulcsszavak:}

„A fizikai életesélyek egyenlötlensége ma azt jelenti, hogy a társadalmi és települési hierarchia, a hatalmi helyzet, a végzett munka jellege, a pénz és a kulturáltság nagymértékben meghatározzák, hogy ki hány évet él, mennyire beteg vagy egészséges, mennyire kellemes körülmények között él, azaz hogyan lakik, eszik, alszik. Ezt a meghatározást ma is érvényesnek tartom. (Ferge 1989 - idézi Ferge 2005, 3)

szociális alapszükségletek szolgáltatás-szervezés rurális kistérség

A tanulmány három, a rurális terekben élö emberek számára fontos szociális alapszolgáltatáshoz kapcsolódó szükségletek mérését és annak modellszerü megoldását keresö kutatás részeredményeit mutatja be. Jelen irás a Nyugat-dunántúli régió rurális kistérségeivel kapcsolatos szükséglet-centrikus adatbáziselemzés elsö tapasztalatait adja közre. A Központi Statisztikai Hivatal T-STAR területi statisztikai adatbázisából gyüitött adatok elemzése, a vizsgálati minta kiválasztását alapozó mutatók rendszerbe foglalása elött a Szerzö a kutatás hátteréröl, mint a közelmúlt kutatási eredményeinek összevetéséról tájékoztatja az Olvasót, majd az adatok elemzésével hidat épit a modell-alkotás következö lépése felé.

\section{A kutatási téma multidimenzionális háttere}

A magyar szociálpolitika legégetóbb kérdése ma az, hogy azok a szociális alapszolgáltatások, amelyek a törvényi szabályozás szerint minden településen elérhetóek kell, hogy legyenek, vajon hogyan válhatnak valóban azzá? A válasz ma leginkább az elaprózott, „egy település- egy önkormányzat” elvén múködő önkormányzati rendszer megújítására épül azáltal, hogy ösztönző támogatást nyújt az önkormányzatok társulásos együttmüködéséhez, a közös szolgáltatás-szervezéshez. Ezt nevezi a magyar közigazgatási rendszer „többcélú kistérségi társulásos együttmüködésnek", amely a statisztikai kistérségek szociális ellátórendszerének fejlesztésében 2004 óta törvényi szinten szabályozott lehetőséget, ugyanakkor a gyakorlatban finanszírozási és szolgáltatási kényszert is jelent az egyes önkormányzatok számára.

A szolgáltatásszervezés vagy önkormányzati feladattelepítés újragondolásának oka az, hogy óriási szakadék tátong a jogszabályi elképzelések, a szociális szolgál- 
Peisser-Puli Edit : Szociális alapszükségletek mérése Magyarország rurális kistérségeiben. Tér és Társadalom 23. évf. 2009/1. 79-99. p.

tatások finanszírozása és a valós szükségletek ismerete között. Minél kisebb egy település - azaz lakosságszáma minél kevesebb - annál nehezebben tudja saját forrásaival kiegészíteni a központi költségvetésböl kapott normatív állami támogatást, így hiába szeretné, nem tudja megszervezni a kötelezö alapszolgáltatásokat sem, holott a szociális szükségletek éppen ezeken a településeken sokszorozódnak meg, és maradnak kielégítetlenek. A téma multidimenzionalitása tehát a közigazgatás gazdaság - társadalom tengelyre füzhető fel, kiegészítve ezt a szociálpolitika és a vidékfejlesztés dimenzióival, mint egy-egy kiinduló- illetve végponttal.

Kutatásunk, amely a szociális szükségletek méréséröl szól, arra kíváncsi, hogy milyen adatok, ismeretek birtokában készülnek el a többcélú kistérségi társulások müködéséhez szükséges helyzetelemzések, és ezek felfoghatók-e a kistérségben élő emberek szociális szükségleteinek megfogalmazásaiként, vagy „csupán” a törvénynek való megfelelési kényszerek? Kissé naiv kérdésünkre sejtjük ugyan a választ, mégis érdekes, hogy milyen konkrét adatokból vonnak le döntéshozók szükségletorientáltnak hitt következtetéseket, és vannak-e modellértékủ kezdeményezések ezen a téren? Célunk az, hogy ezekkel vagy ezek hiányában létrehozzunk egy, a rurális terek többcélú kistérségi társulásos szolgáltatás-szervezésében értelmezhető és használható szociális szolgáltatástervezési modellt arra a három alapszolgáltatásra, amelyek közül kettő lakosságszámtól függetlenül minden településen kötelezöen szervezendö, egy pedig ugyan a rurális terekre Magyarországon kevésbé jellemző 10 ezer föt meghaladó településeken kötelezö, de a szükségletek vonatkozásában már jogszabályi szinten is kapcsolt szolgáltatása az előbbieknek. Az 1. táblázat áttekintést ad a szociális alapszolgáltatások rendszerérỏl; a kutatásban vizsgálandó szolgáltatások dólt betúvel szedve olvashatók.

Nem beszélhetünk addig az életminőség széles körü javításáról vagy annak szándékáról, amíg nem célzott társadalmi csoportoknak hozunk létre célzott szolgáltatásokat. Különösen nem, ha figyelmen kívül hagyjuk az életminőséget befolyásoló szolgáltatásszervezési szempontokat, mint valódi együttmüködés. Azaz kistérségi szemlélet a különböző települési aktorok között, integráció; hatékonyabb és színvonalasabb ellátások kialakítása, átláthatóság; elérhető, informált, akadálymentes szolgáltatások, szakmai minöséget és fenntarthatóságot mutató szolgáltatások természetesen a különböző területi szinteknek megfelelően - településen, mikrotérségben, kistérségben, megyében, régióban. 
Peisser-Puli Edit : Szociális alapszükségletek mérése Magyarország rurális kistérségeiben. Tér és Társadalom 23. évf. 2009/1. 79-99. p.

TÉT XXIII. évf. 2009 a 1

Gyors ténykép

81

\section{TÁBLÁZAT \\ Szociális alapszolgáltatások Magyarországon (Basic Social Services in Hungary)}

\begin{tabular}{|c|c|}
\hline $\begin{array}{c}\text { A szolgáltatás } \\
\text { neve }\end{array}$ & A szolgáltatás célja \\
\hline Étkeztetés & $\begin{array}{l}\text { Az étkeztetés keretében azoknak a szociálisan rászorultaknak a } \\
\text { napi legalább egyszeri meleg étkeztetéséröl kell gondoskodni, } \\
\text { akik azt önmaguk, illetve eltartottjaik részére tartósan, vagy } \\
\text { átmeneti jelleggel nem képesek biztositani, különösen konuk, } \\
\text { egészségi állapotuk, fogyatékosságuk, pszichiátriai betegségük, } \\
\text { szenvedélybetegségük vagy hajléktalanságuk miatt. }\end{array}$ \\
\hline $\begin{array}{l}\text { Házi segitségnyúj- } \\
\text { tás }\end{array}$ & $\begin{array}{l}\text { A házi segitségnyrijtás keretében a szolgáltatást igénybe vevó } \\
\text { személy saját lakókörnyezetében biztositani kell az önálló } \\
\text { életvitel fenntartása érdekében szükséges ellátást: az alapvetö } \\
\text { gondozási-ápolási feladatokat, az ellátott és lakókörnyezete } \\
\text { higiéniás körrilményeinek megtartásában való közremükö- } \\
\text { dést, a veszélyhelyzetek megelözésében és azok elháritásában } \\
\text { való segítségnyújtást. }\end{array}$ \\
\hline
\end{tabular}

Falu- és tanyagondnoki szolgáltatás

Családsegítés

Nappali ellátás

$$
\begin{gathered}
\text { Jelzörendszeres } \\
\text { házi segitség- } \\
\text { nyújtás }
\end{gathered}
$$

Támogató szolgálat

Közösségi ellátás

Utcai szociális munka
Célja az aprófalvak vagy tanyasi lakott helyek intézményhiányából eredó hátrányainak enyhítése, az alapvetö szuikségleteket kielégitő szolgáltatásokhoz, kỏzszolgáltatásokhoz, valamint egyes alapszolgáltatásokhoz való hozzájutás biztositása, továbbá az egyéni és közösségi sziükségletek teljesitésének segítése.

A szociális vagy mentálhigiénés problémák, illetve egyéb krízishelyzet miatt segítségre szoruló személyek, családok számára az ilyen helyzethez vezető okok megelőzése, a krízishelyzet megszüntetése, valamint az életvezetési képesség megórzése céljából nyújtott szolgáltatás.

Koruk, egészségi állapotuk, pszichiátriai vagy szenvedélybetegségük, fogyatékuk vagy autizmusuk miatt önellátásra részben képes személyek számára biztosít lehetőséget a napközbeni tartózkodásra, társas kapcsolatokra, alapvetỏ higiéniai szükségleteik kielégítésére, igény szerinti étkeztetésre.

A saját otthonukban élö, egészségi állapotuk vagy szociális helyzetük miatt rászoruló, a segélyhivó készülék megfelelö használatóra képes időskorí vagy fogyatékos személyek, pszichiátriai betegek részére az önálló életvitel fenntartása mellett felmerüló krizishelyzetek elháritása céljából nyújtott ellátás.

Fogyatékkal élö emberek lakókönyezetben való ellátása, a lakáson kívüli közszolgáltatások elérésének segítése, önálló életvitelük fenntartása, lakáson belüli speciális segítségnyújtás.

A pszichiátriai, illetve szenvedélybetegek részére nyújtott közösségi alapellátás és a szenvedélybetegek részére nyújtott alacsonykủszöbú szolgáltatás: lakókömyezetben nyújtott segítség az önálló életvitel megőrzéséért, meglévő képességek megtartása és fejlesztése, szakorvosokkal való kapcsolattartás, folyamatos figyelemmel kísérés, megkeresỏ programok szervezése, ártalomcsökkentö szolgáltatások és kríziskezelés.

Az utcán tartózkodó hajléktalan személyek helyzetének, életkörülményeinek figyelemmel kísérése, szükség esetén ellátásának kezdeményezése, a kapcsolódó intézkedések megtétele.
Lakosságszám

Minden

településen

Minden

településen

600 fó alatt, $\max .660$ föig; illetve és 40-700

föig

2000 fó felett

3000 fó felett

10 ezer fó felett, de többcélú

kistérségi társu-

lásos egyittmü-

ködéssel minden településen

10 ezer fö felett

10 ezer fö felett

50 ezer fö felett

Forrás: Saját szerkesztés a többszőrỏsen módosított 1993. évi III. törvény a szociális igazgatásról és a szociális ellátásokról 56-65/F. § alapján. 
Peisser-Puli Edit : Szociális alapszükségletek mérése Magyarország rurális kistérségeiben.

Tér és Társadalom 23. évf. 2009/1. 79-99. p.

82 Gyors ténykép

TÉT XXIII. évf. 2009

\section{1. ÁBRA}

Hármas-metszet: szabályozás - finanszirozás - ismeret

(Triple-segment: Regulation - Financing - Knowledge)

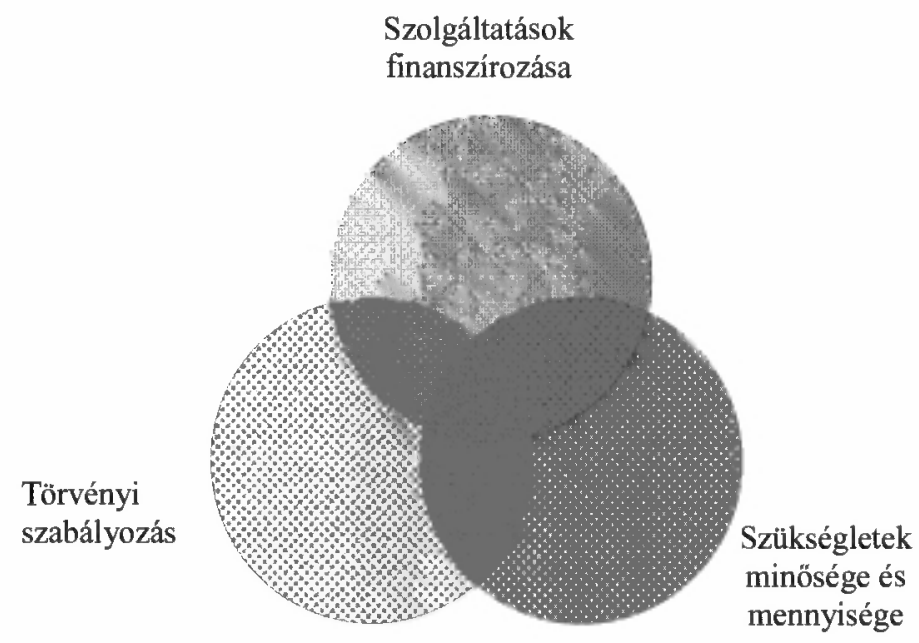

Forrás: Saját szerkesztés.

$\mathrm{Az}$ 1. ábra üzenete nem más, mint az a sajátos gondolkodásmód, amely ma meghatározza a szociális alapszolgáltatások szervezését és müködését. Látható, hogy a törvényi szabályozás - a szolgáltatások finanszírozása - és a szükségletekról való tudás hármasa tetszőlegesen kerül egymás mellé, egymáshoz való kapcsolódásuk nem rendezett, ezáltal funkciójuk is megkérdőjeleződik. Példaszerüen támasztja alá a fenti allításokat az is, hogy az Állami Számvevőszék 2007 nyarán készítette el jelentését az önkormányzatok szociális alapszolgáltatási tevékenységének ellenörzéséról. Berényi és szerzötársai (2007) összegző megállapításai lényeglátóak és egyben jó alapot adnak a helyzet megváltoztatásának elindításához. Ezek szerint:

- a szociális alapszolgáltatások intézményrendszerének kialakításakor, 1993-ban készültek lakossági szükségletfelmérések, de az ellátások átalakítására nem készült sem rövid, sem hosszú távú koncepció;

- ,(..) nincsen naprakész nyilvántartási rendszer, amely követhető adatokkal támasztaná alá a müködő szolgáltatások típusait, az ellátottak számát és az egyes szolgáltatások iránti szükségleteket" (Berényi et al 2007, 10);

- az, hogy az étkeztetést és házi segítségnyújtást lakosságszámtól független kötelező alapszolgáltatásként határozták meg, nem járt együtt az önkormányzatok teherbíró képességének figyelembevételével és a valós lakossági szükségletek mérésével; 
Peisser-Puli Edit : Szociális alapszükségletek mérése Magyarország rurális kistérségeiben. Tér és Társadalom 23. évf. 2009/1. 79-99. p.

- a számos alapszolgáltatás miatt az ellátórendszer szétaprózódott és annak szabályozása túl bonyolult;

- a 15 éve hatályban lévő Szociális törvény 49 alkalommal módosult;

- az állandó módosítások ellentmondásos jogszabályi környezetet eredményeztek;

- miután nincsenek meghatározva a szolgáltatások minimális ellátottsági mutatói, az önkormányzatok igen heterogén mennyiségủ és minőségủ szolgáltatásokat működtetnek;

- nem biztosított valamennyi településen a szolgáltatások célzottsága, az igazságosság és az esélyegyenlöség elve sérül;

- az ellátórendszer nem átlátható, és ugyan vannak törekvések a kommunikáció szintjén a költséghatékonyság és gazdaságosság követelményének teljesítésére, nincsenek ilyen irányú minisztériumi vizsgálatok;

- nőtt a települési egyenlötlenség, az ellátási hiátusok éppen azokat a településeket érintik, ahol a legnagyobb szükség lenne rájuk;

- torz a rendszer, mert miközben leírja az alapszolgáltatások és szakosított ellátások egymásra épülésének elvét, éppen ennek a folyamatnak az ellenében müködik: a hiányzó alapszolgáltatások a szakellátások felé tolják el a szüikségleteket abszolút nem preventív, hanem korrektív módon, így az önellátásra épülő alapszolgáltatási rendszer elve önmagát semmisíti meg;

- a lakosságszámhoz, feladatmutatóhoz kötött támogatási rendszer egyensúlytalanságot okoz a finanszírozásban; a szükségletek koordinációja nélkül befogadott szükségletek többletkiadásokat okoznak;

- nem készülttek elemzések arra vonatkozóan, hogy a társulásos feladatellátás ösztönző támogatásai hogyan hatottak a szolgáltatások mennyiségére és minőségére';

- a hátrányos helyzetủ kistérségek fejlesztésére 2001 óta működő kistérségi szociális felzárkóztatási programok nem jártak érdemi eredménnyel, mert a fejlesztési projektek nem igazodtak a Szociális törvény szolgáltatásainak biztosításához, illetve hiányoznak azok a mutatók, amelyek mentén értékelést lehetne végezni;

- „(...) a normatíva 2004-ben 66,6, 2005-ben 64,4\%-át fedezte a szociális szolgáltatások múködtetésének, önkormányzati forrásokra minden évben szükség volt, ezek azonban csak 8-8,6\%-át biztosították a kiadásoknak, tehát a forráshiány mindkét évben egyértelmü volt." (Berényi et al 2007, 14);

- az étkeztetést az egyik legfontosabb szociális alapszolgáltatásként említi a jelentés, ,(...) amely 2001-től évente több mint 100000 ember számára elérhető, az adatok szerint az étkeztetésben részesülők száma emelkedik, évente 10\%-kal, 2005-ben 3956-an étkeztek a vizsgált 333 település 335069 fös népességéböl, így megvalósult az a jogalkotói szándék, hogy a kistelepüléseken többen részesüljenek a szolgáltatásban." (Berényi et al 2007, 14);

- ,(...) a házi segítségnyújtásban részesülők száma 2004-ről 2005-re 17,6\%-kal emelkedett, sőt, a tízezer 60 éven felüli lakosra jutó ellátottak száma az 1000 fố alatti településeken az országos átlagot meghaladó, mert a fiatalok elköltözése miatt az idősödő népesség nagyobb arányban igényli ezt a szolgáltatást." (Berényi et al 2007, 14); 
Peisser-Puli Edit : Szociális alapszükségletek mérése Magyarország rurális kistérségeiben. Tér és Társadalom 23. évf. 2009/1. 79-99. p.

- a jelzőrendszeres házi segítségnyújtás társulásos támogatása ösztönzi az önkormányzatok együttmüködését, mert saját forrásokat nem kell mozgósítani a szolgáltatás megszervezéséhez;

- a többcélú kistérségi társulások megjelenésével az önkormányzatok feladatellátása átalakult, általuk növekszik a hiányzó szolgáltatások megszervezése.

$\mathrm{Az}$ ÁSZ javasolja a szociális alapszolgáltatások iránti igények és szükségletek felmérésének bevezetését, a meglévő statisztikai adatbázisok tartalmának felülvizsgálatát és a Szociális törvény módosítását annak érdekében, „,hogy a szociális alapszolgáltatások minden településen elérhetőek legyenek." (Berényi et al 2007, 17)

Mindjárt fel kell erősítenünk a szakmai kutatások (Papházi 2002; Hodosán 2003; Bácskay 2005) és az Állami Számvevőszék jelentésének (Berényi et al 2007) ellentmondását az étkeztetés és a házi segítségnyújtás vonatkozásában, hiszen előbbiek szolgáltatási csökkenést, utóbbi évi 10\%-os növekedést mond, hovatovább kiemeli a kistelepülések hozzáférési egyenlőtlenségének csökkenését is. Ezzel a paradoxonnal kutatásunk ismét alátámasztást nyer, hiszen mindegyik állítás kutatási eredményekre alapozott, saját vizsgálódásunk az adatbázisokban valószínủleg hozzáad újabb információkat az eddigiekhez.

Papházi Tibor (2002) Kistelepülések szociális ellátó tevékenységéról statisztikai adatok alapján címü tanulmányában az alapszolgáltatásokról a következő megállapítást teszi: „Ha a szociális törvényszerinti településnagyságokat összevetjük az adatbázisból vizsgálható alapellátásokkal ${ }^{2}$, akkor kiderül, hogy elsősorban a kistelepüléseken nincsenek ellátottak, bár a szociális törvény az ellátást ezeken a településeken is kötelezővé teszi. Részletesebben nézve 2000-ben az $1163 \mathrm{db} 600$ fö alatti település 55,3\%-ában nem volt étkeztetett, 89,8\%-ában nem volt házi segítségnyújtásban részesülö, $85,1 \%$-ában nem tartottak nyilván olyan személyt, aki mindkét ellátásban egyszerre részesült." (Papházi 2002, 17) Két nagyon fontos reflexió kívánkozik ide. Az egyik az, hogy a törvényi településméret vagy lakosságszám ${ }^{3}$ meghatározása sajátossá teszi a szolgáltatási paletta elemzését például akkor, amikor 70-400 fö lakoshoz köti a tanyagondnoki ellátás és 600 fó alatti településeken teszi lehetővé a falugondnoki szolgálat megszervezését. A fenti kutatás ezekhez a paraméterekhez alkalmazkodik, és ugyan tudjuk, hogy a valóságban nincsenek számottevő különbségek az 500 illetve 600 fös települések gazdasági-társadalmi helyzetei között, mégis némi diszkrepancia keletkezik a települések lélekszám szerinti besorolása és elemzése között. A másik fontos észrevétel a kutatás tartalmával kapcsolatban az a paradoxon, amely a településnagyság-kategória kifejezés mögött húzódik: „(..) a kisebb településeken a népességszámhoz viszonyított összes ellátotti arány átlagosan magasabb, mint a nagyobb településeken." (Papházi 2002, 17)

Hodosán Róza (2003) Alapellátási kötelezettségek - kistelepülési stratégiák címủ tanulmányát fontosnak és kutatásunk szempontjából továbbgondolásra alkalmasnak tartjuk. Integratív szemléletével, az ezredfordulón elkészült szakmapolitikai felmérések és reflexiók beemelésével és azok tapasztalatainak kiterjesztésével, az 500 fó 
Peisser-Puli Edit : Szociális alapszükségletek mérése Magyarország rurális kistérségeiben. Tér és Társadalom 23. évf. 2009/1. 79-99. p.

alatti aprófalvak mellett a rurális terekben egyre veszélyeztetettebbnek látszó kistelepülésekre fókuszáltan vizsgálja meg és elemzi a szociális alapszolgáltatások feltételrendszerét, müködését és hiányait, minden fontos kapcsolódó jellemzőjét, amely a szociális szükségletek modellezése szempontjából alapvetö. Két meghatározó szakmai vizsgálatra, illetve dokumentumra hivatkozik a szerző már kiindulási alapként. Az egyik „A szociális és gyermekjóléti alapellátások helyzetének áttekintése” (2001), a másik a „Szociális ellátási térkép 1997-2000” című elemzés. Ez a két írás azt tárgyalta, hogyan feleltek meg az önkormányzatok a vonatkozó törvényi elöírásoknak szolgáltatási kötelezettségeik tekintetében. Mindkét elemzés summázata szerint a törvényi kötelezettségek ellenére hiányosságok és visszaesések tapasztalhatók a hagyományos alapszolgáltatásokban, fóként az étkeztetés és a házi segítségnyújtás terén, növekedés a családsegítésben, a gyermekjóléti szolgáltatásokban és a falu- és tanyagondnoki szolgáltatások vonatkozásában látható. Itt is megjelenik az „urbanizációs lejtő” abban a megfogalmazásban, hogy ,(...) a települések létszámcsökkenésének mentén csökken az ellátások biztosítottsága, (...) és létezik a településeknek egy olyan köre, amelyik nem vagy kevésbé tudja teljesíteni kötelezettségeit." (Hodosán 2003, 2) A kutatás célja elsősorban ${ }^{4}$ az volt, hogy feltérképezze: hogyan tudja a helyi közösség kielégíteni a szociális intézményekkel nem lefedett, de létező szociális alapszolgáltatási szükségleteket? 30 település három lakosságszám kategóriájában: 500 fó alatti, 501-1000 fős és 1001-2000 fỏs készült el az elemzés. Nézzük meg e kutatás tapasztalatait sorban ahhoz, hogy reflektálni tudjunk a szükségletek mérésének kérdésére.

Az 500 fơ alatti települések összefoglalt jellemzői:

- elöregedés;

- alacsony gyermekszám;

- a tanácsi körzetesítés okán megszünt intézmények: iskolák;

- elvándorló fiatalok;

- megszünt munkahelyek, visszafordíthatatlannak tünő láncreakcióban;

- ezzel párhuzamosan az infrastruktúra fejlödése, ha kisléptékben is, de minden településen;

- az önállósodás eufemisztikus érzése megszépíti a jelent, az önálló települési döntések és az önálló gazdálkodás a fejletlenséget is átértelmezi a lakossảg körében;

- ezért az önkormányzatok nem keresik a társulásos együttmúködési lehetőségeket, még akkor sem, ha az önállóság valamely szolgáltatás müködtetését veszélyezteti;

- vezetői agilitás determinációja az infrastruktúra fejlesztésében, emellett össztelepülési összefogás, pályázati lehetőségek kutatásában, lobbytevékenységben;

- hiszen az önkormányzati öneró nem elegendö;

- a földrajzi elhelyezkedés jelentősége a rossz közlekedési helyzettel és elzártsággal küzdő falvakban a munkalehetőségek szempontjából is kiemelkedő,

- mert növelik a munkanélküliséget, a szociális ellátásokra szoruló lakosok számát; 
- az önkormányzati bevételek szinte teljes hányadát a központi költségvetés redisztribúciója adja;

- a helyi saját bevételek elenyészőek, melynek következménye a rendkívül szük mozgástér a nem kötelező feladatok ellátásában;

- magas, egyharmadnyi az önhibájukon kívül hátrányos helyzetbe került önkormányzatok aránya, azaz fokozott a központi kiegészítés a kötelezö feladatok ellátásában.

A mintába került tíz 500 fö alatti településből kettőben müködik falugondnoki szolgálat, sem étkeztetés, sem házi segítségnyújtás nincsen négy településen, csak étkeztetés van kettő településen, étkeztetés és házi segítségnyújtás is müködik négy településen, miközben szociális térkép, azaz a valós szükségletek felmérése egyetlen településen sem készült, a ,jól ismert okok” miatt: „,mindenki ismer mindenkit”. Általános kutatási tapasztalat a szakdolgozati szintủ elemzésekben is a „szubjektiv ismeretanyagra" (Hodosán 2003, 6) való támaszkodás a szükségletek felmérése helyett vagy azok elfedésére. Ösztönszerủ cselekedet ez és egyben védekezési mechanizmus is: a rövid távú ellenérdekeltség a finanszírozási nehézségek miatt hoszszú távú veszteségeket, irreverzibilis folyamatokat generál. A kutatás lényege, hogy hasonlóan rossz tendenciákat vél felfedezni az 501-1000 fös települések vizsgálatakor is, azzal a meglepő megállapítással, hogy ezek ,(..) a településeink minden tekintetben - gazdaság, infrastruktúra, munkaeröhelyzet - rosszabb képet mutatnak, mint a legkisebb települések." (Hodosán 2003, 8). Ugyanakkor relative több szolgáltatást biztosítanak az étkezetés és a házi segítségnyújtás terén (a tízből mindöszsze egy településen nem elérhető egyik szolgáltatás sem). Meglepőnek tủnő eredmény a következő település-kategória típusban (1001-2000fö) is akad: itt már lényegesen nagyobbak a különbségek az egyes települések helyzete, ebböl adódóan lehetőségei szempontjából, mert a földrajzi elhelyezkedés, a többszörösen hátrányos helyzetủ régióban vagy kistérségben való elhelyezkedés a generális kötelezettséget ellehetetleníti. Vitatkozunk a szerzővel abban, hogy jól müködő immunrendszer lenne a falu, ahol a szubjektív ismeretanyagra lehet támaszkodni a szükségletek beazonosításakor, hiszen a közelség, a másikról való tudás nem jár együtt minden esetben a szükségletek jelzésével, vagy azok kielégítésével közösségi szinten.

Bácskay Andrea statisztikai adatelemzésen alapuló 2004-es kutatása a népességnagyság-kategória szerinti alapszolgáltatási hozzáférést írja le. Olyan megállapításokat tesz, miszerint: „(...) minél nagyobb településen élnek a rászorulók, annál kisebb valószínüséggel jutnak ellátáshoz., vagy ,(..) az összes ellátott népességszámhoz viszonyított hányada a kisebb településeken magasabb, mint a nagyobbakon.” és „Ez ellentmondani látszik annak, hogy minél kisebb egy település, annál rosszabb az intézményes ellátottság." (Bácskay 2005, 32). Ez a kutatás 0-499, 500-999, 1000-1999, 2000-4999 (...) 100000 feletti lakosságszám szerinti beosztásban gondolkodik, és csak az 500 fö alatti településeket emeli ki a kisebb, illetve nagyobb település egzaktabb meghatározásaként. A kutatás összefoglaló ismeretei szerint: 
Peisser-Puli Edit : Szociális alapszükségletek mérése Magyarország rurális kistérségeiben. Tér és Társadalom 23. évf. 2009/1. 79-99. p.

- „(..) a házi segítségnyújtás és az étkeztetés biztosításában visszaesés figyelhető meg, az ellátásokat igénybevevők száma 1993 óta csökkent, miközben az időskorúak - különösen a nagyon idősek, 80 éven felüliek - száma és aránya nött;

- elóbbi szolgáltatás a települések felében, az utóbbi pedig a települések egynegyedében nincsen biztosítva;

- megfigyelhető az „urbanizációs lejto”" hatása, azaz minél kísebb a település lélekszáma, annál hiányosabb az ellátás;

- az ellátási problémák a kistelepüléseken koncentrálódnak;

- a kistelepüléseken a szociális ellátórendszer fenntartásának feltételeit a gazdálkodás keretei szabják meg;

- egyre nagyobb számban jelennek meg a nem állami szervezetek, melyek részben a hiányzó önkormányzati szolgáltatásokat pótolják, részben szélesítik az igénybe vehetö szolgáltatások körét, ez a folyamat azonban döntően a bentlakásos ellátás terén zajlik;

- az alapellátás, étkeztetés, házi segítségnyújtás túlnyomórészt még mindig a települési önkormányzatokra hárul;

- a kisebb településeken jelentős arányban jelennek meg a több önkormányzat fenntartásában, illetve másik önkormányzattal kötött ellátási szerződés keretében müködő szolgáltatások is;

- civil szervezetek, vállalkozások elenyészỏ számban szerepelnek ellátóként, ami vélhetően gazdasági okokkal magyarázható elsösorban." (Bácskay 2005, $35 ; 13-14)$

Mindenképpen nagyon is meghatározó hármas metszetröl lenne szó tehát akkor, ha tisztázott lenne a szükségletek köre elsősorban minőségi és másodsorban menynyiségi vonatkozásban, ha ezen ismeretekre alapulna a törvény szabályozta szolgáltatás-szervezési kötelezettség, és erre épülne a szolgáltatások finanszírozása a 2. ábra szerint.

Mindenképpen elmondható végül, hogy az idézett elméleti írások inkább alátámasztják a kutatás problematikáját: azaz a szociális szükségletek mérésére most különösen szükség van, hiszen egymásnak ellentmondó adatokkal írhatók le az alapszolgáltatások. Ennek térbeli vetülete az, hogy a rurális térségek szolgáltatási egyenlötlenségének nagyfokú ténye miatt - a szociálpolitikában aprófalvas térségként vagy településként definiált közegben - ez fokozott szakmai és igénybevevői érdek, amely ugyan nem találkozik önkormányzati, döntéshozói érdekekkel, mégis befolyásolhatják azokat. 
Peisser-Puli Edit : Szociális alapszükségletek mérése Magyarország rurális kistérségeiben.

Tér és Társadalom 23. évf. 2009/1. 79-99. p.

\title{
2. ÁBRA
}

Mért és valós szükségleten alapuló szolgáltatás-szervezés (Service Organisation Based on a Survey of Real Needs)

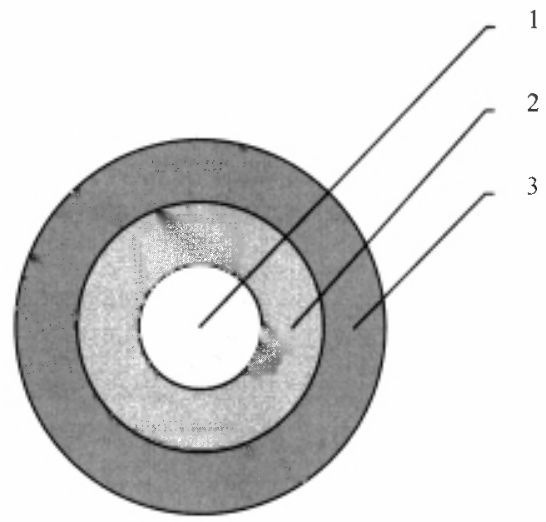

\begin{abstract}
Megjegyzés:
1) Mért, ezáltal valós szükségletek; 2) Szükségletcentrikus szabályozás; 3) Hatékonyabb, a szükségletekhez alkalmazkodó finanszírozás.
\end{abstract}

Forrás: Saját szerkesztés.

\section{A kutatási minta kiválasztása - hátrányos helyzetü rurális kistérségek}

Ahhoz, hogy a rurális kistérségek szociális alapszolgáltatási rendszerét a szükségletek oldaláról vizsgálni lehessen, olyan mutatókra van szükség, amelyek önmagukban egyenként is, de együtt is leírhatják a három kiemelten vizsgált alapszolgáltatás: az étkeztetés, a házi segítségnyújtás és/vagy a jelzörendszeres házi segítségnyújtás szükségleteit. Első lépésben tehát meg kell találni az egymással kapcsolatba hozható mutatók körét, amelyek jelenleg szétszórtan állnak rendelkezésre a különböző statisztikai leírásokban és adatbázisokban.

A minta kiindulási nagysága a Nyugat-dunántúli régió ${ }^{5} 25$ statisztikai kistérsége volt, amelyek természetesen nem felelhetnek meg a „legalább egy szempontból homogén minta" szabályának, hiszen városias és vidékies tereket egyaránt jelentenek.

A 120 fö/ $/ \mathrm{km}^{2}$ alatti népsủrüségú településeken élők aránya mutatószámmal mért ruralitás szerint 25-röl felére csökken a mintába vonható kistérségek száma, hiszen városias kistérsége csupán egy akad a régiónak, a Györi kistérség. Ezen túl abszolút vidékies, illetve erőteljesen vidékies és vidékies a kistérségek közül $12^{6}$, amint azt a 3. ábra is mutatja. 
Peisser-Puli Edit : Szociális alapszükségletek mérése Magyarország rurális kistérségeiben. Tér és Társadalom 23. évf. 2009/1. 79-99. p.

TÉT XXIII. évf. 2009 - 1

Gyors ténykép

\section{3. ÁBRA}

Magyarország és a Nyugat-dunántúli régió vidékies kistérségei (Hungary and the Rural Subregions in the Western Transdanubian Region)

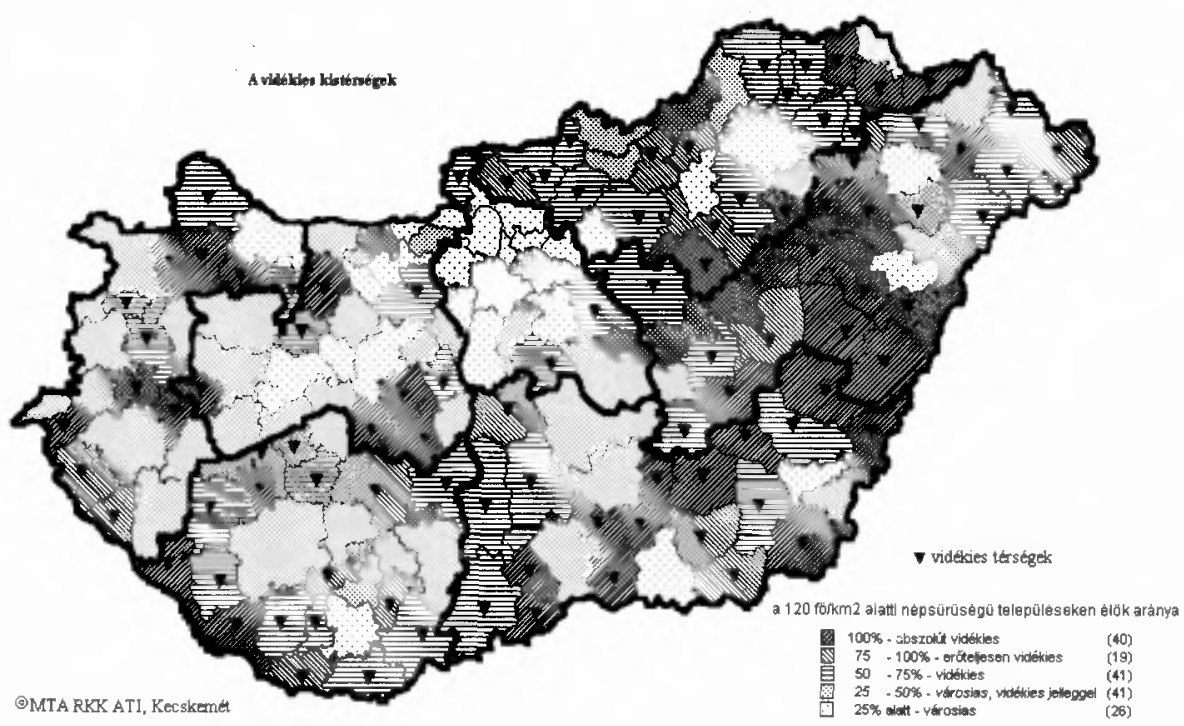

Megjegyzés: A 2007. évi CVII. törvény alapján 174 kistérség van az országban.

Forrás: MTA RRK ATI.

Az egyes megyei ${ }^{7}$ statisztikai tükrökben, kistérségi leírásokban, a kedvezményezett térségek lehatárolásáról szóló területfejlesztési jogszabályokban további elemzési mutatókat találtunk:

- a település szerkezet,

- a települések átlagos lélekszáma,

- a korszerkezet vagy öregségi index,

- a nyugdíjban vagy nyugdíjszerü ellátásban részesülők száma,

- a kistérségi átlagnyugdíj,

- a szociális ellátások és igényeik alakulása,

- a kistérségi komplex mutató

- és a kedvezményezett kistérségek száma, összetett mutató-rendszerrel.

Ezek az adatok megtalálhatók a fent emlitett forrásokban, tehát az aktuális helyzetelemzésre minden bizonnyal felhasználhatók. A mutatórendszer két funkciót tölt be egyszerre, egyrészt természetesen a rurális terek pontosabb lehatárolásához segít hozzá, azaz kiemeli azokat a kistérségeket, ahol a legalapvetőbb három alapszolgáltatásra a legnagyobb szükség lehet, másrészt kiindulási alapja és továbbfejleszthető mutatórendszere a szükségletek mérhetővé tételének. Ez a két funkció ugyanannak az éremnek a két oldala, de mindkét oldal a szükségletek mérése felé jelenti az első lépcsőt. 
Peisser-Puli Edit : Szociális alapszükségletek mérése Magyarország rurális kistérségeiben.

Tér és Társadalom 23. évf. 2009/1. 79-99. p.

4. ÁBRA

Mutatók rendszere a szükségletek méréséhez (The System of Indicators for Measuring Needs)

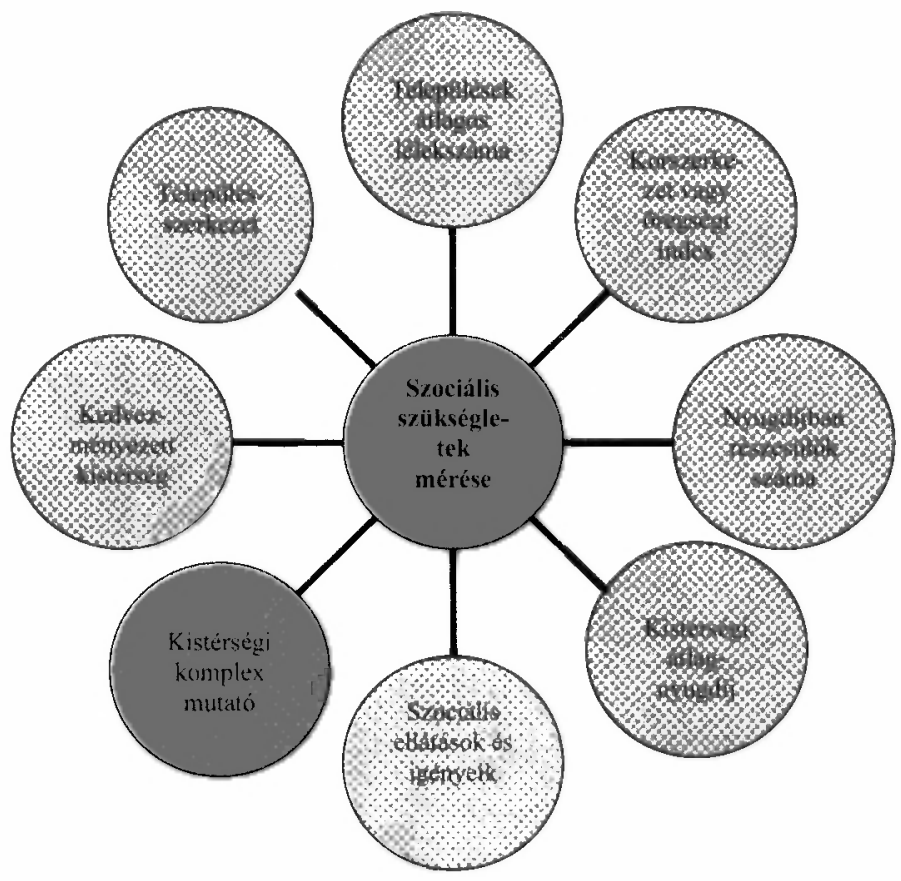

Forrás: Saját szerkesztés.

A nyolc mutató (4. ábra) közül az egyik legösszetettebb a kistérségi komplex mutató, amely a kistérségek kedvezményezetti helyzetének meghatározására szolgál gazdasági, infrastrukturális, társadalmi, szociális és foglalkoztatási mutatók (összesen jelenleg 31) segitségével. A kistérségi komplex mutató alapján a kutatási mintába bekerült kistérségeket a 2. táblázat mutatja.

Láthatjuk, hogy az országos átlagnak $(2,9)$ mindössze három kistérség tudott fölékerekedni, mégis a minta nagyon informatív tagjai lesznek, hiszen átmenetileg kedvezményezett besorolást kaptak alacsony komplex mutatójuk alapján. „Társadalmigazdasági szempontból elmaradott térségnek kell minősíteni azokat a statisztikai vonzáskörzeteket, amelyeknek az 5 mutatószám csoportból kẻpzett komplex mutatója nem éri el az országos átlagot." - mondja a 67/2007. (VI. 28. ) Országgyúlési határozat melléklete. 
Peisser-Puli Edit : Szociális alapszükségletek mérése Magyarország rurális kistérségeiben. Tér és Társadalom 23. évf. 2009/1. 79-99. p.

TÉT XXIII. évf. 2009 — 1

Gyors ténykép

\section{TÁBLÁZAT}

A nyugat-dunántúli régió vizsgálható rurális kistérségei (Rural Subregions in Western Transdanubia for Examination)

\begin{tabular}{|c|c|c|c|c|}
\hline Megye & Kistérség & $\begin{array}{c}\text { Komplex } \\
\text { mutató } \\
(1-5 \text { pont- } \\
\text { szám) }\end{array}$ & $\begin{array}{l}\text { Lakosság- } \\
\text { szám }\end{array}$ & $\begin{array}{l}\text { Kedvezményezett! } \\
\text { átmenetileg kedvez- } \\
\text { ményezett kistérség }\end{array}$ \\
\hline \multirow[t]{2}{*}{$\begin{array}{l}\text { Györ- } \\
\text { Moson- } \\
\text { Sopron }\end{array}$} & Téti & 2,99 & 19246 fö & $\begin{array}{l}\text { Átmenetileg } \\
\text { kedvezményezett }\end{array}$ \\
\hline & Csornai & 3,15 & 39904 fö & $\begin{array}{l}\text { Átmenetileg } \\
\text { kedvezményezett }\end{array}$ \\
\hline \multirow[t]{3}{*}{ Vas } & Vasvári & 2,55 & 14552 fó & Hátrányos helyzetủ \\
\hline & Celldömölki & 3,06 & 25670 fö & $\begin{array}{l}\text { Átmenetileg } \\
\text { kedvezményezett }\end{array}$ \\
\hline & Öriszentpéteri & 2,63 & 6937 fö & Hátrányos helyzetủ \\
\hline \multirow[t]{4}{*}{ Zala } & Letenyei & 2,56 & 17391 fö & Hátrányos helyzetủ \\
\hline & Pacsai & 2,59 & 10792 fö & Hátrányos helyzetủ \\
\hline & Zalakarosi & 2,63 & 13196 fó & Hátrányos helyzetü \\
\hline & Zalaszentgróti & 2,80 & 18238 fó & Hátrányos helyzetủ \\
\hline
\end{tabular}

Forrás: Saját szerkesztés.

„A szociális ellátások és igényeik" mutatószám a másik nagyon meghatározó mutató a szociális szükségletek mérésének szempontjából, ezekre a tanulmány első fejezetében már hivatkoztunk adatokat.

A következö, egyben lényegi fejezete a tanulmánynak az adatbázis-elemzés részeredményeit foglalja össze és veti egybe a szakmai-állami adatokkal, kifejezetten azért, hogy a mutató-rendszer felépítése után láthassuk a mintába bevont 9 kistérség szociális szükségleteit. Ezzel tulajdonképpen a helyzetelemzés fázisának teszünk eleget.

\section{Kistérségek föbb jellemzöi szekunder adatok alapján}

A továbbiakban a három szociális alapszükséglet mérési modelljéhez szükséges adatbázis elemzésére és eredményeinek összefoglaló leírására kerül sor, összevetve az első fejezetben citált szakmai és döntéshozói megállapításokkal. A nyolc mutatóból képzett mutató-rendszer (4. ábra) adta a Központi Statisztikai Hivatal és annak T-STAR alrendszerében aktuálisan megtalálható adatok kiválasztási szempontjait, amelyeket a szociálpolitikai szakirodalom, a különböző adatbázisok (KSH, T-STAR, 
Peisser-Puli Edit : Szociális alapszükségletek mérése Magyarország rurális kistérségeiben.

Tér és Társadalom 23. évf. 2009/1. 79-99. p.

TeIR) kínálata és az ún. állami-döntéshozói dokumentumok (pl. Állami Számvevöszéki Jelentés [Berényi et al 2007]) segítségével gyüjtöttük össze. Ezek azok a mutatók, amelyek az említett forrásokban szinte mindig megjelennek, azaz használatosak, de eleddig nem kapcsolódtak össze egymással a szociális alapszükségletek szempontjából. Az alábbi elemzésben fontos szempontnak tartjuk a ruralitáshoz kapcsolódó szükséglet-centrikus keretet, ezért elöször a település-szerkezet és a települések átlagos lélekszáma kerül bemutatásra, majd ezt követi az öregedési index, a nyugdijban részesülök száma és az átlagnyugdíj, végül, de nem utolsó sorban a „,szociális igényekként" aposztrofált adatcsoport. A komplex mutató és a kedvezményezetti besorolás már teret kapott a tanulmány második fejezetében, ezekre csak hivatkozunk.

Település-szerkezet és népességszám

\begin{tabular}{|c|c|c|c|c|}
\hline \multicolumn{5}{|c|}{$\begin{array}{c}\text { 3. TÁBLÁZAT } \\
\text { Település-szerkezet és népességszám } \\
\text { (Settlement Structure and Number of Population) }\end{array}$} \\
\hline Területi egység & $\begin{array}{l}5000 \text { fó alatti } \\
\text { települések } \\
\text { aránya (\%) }\end{array}$ & $\begin{array}{c}2000 f^{\prime \prime} \\
\text { alatti } \\
\text { települések } \\
\text { aránya }(\%)\end{array}$ & $\begin{array}{l}\text { 5000 fö alatti } \\
\text { településen } \\
\text { élók száma } \\
\text { (fó) }\end{array}$ & $\begin{array}{c}5000 \text { fó feletti } \\
\text { településen } \\
\text { élók száma } \\
\text { (fó) } \\
\end{array}$ \\
\hline $\begin{array}{l}\text { Győr-Moson- } \\
\text { Sopron megye }\end{array}$ & 96,7 & 83,5 & 196400 & 242616 \\
\hline Vas megye & 97,2 & 93,2 & 125844 & 141585 \\
\hline Zala megye & 98,0 & 95,3 & 145682 & 152171 \\
\hline Ország & 91,2 & 75,1 & 3237827 & 6904535 \\
\hline
\end{tabular}

Forrás: KSH (2006) alapján saját szerkesztés.

A Nyugat-dunántúli régió mindhárom megyéjében ${ }^{8}$ mindenütt meghaladja az országos átlagot a kistelepülések aránya, különösen a zalai kistérségek aprófalvas település-szerkezete szembeötlö. A 2000 fơs települési lélekszám a szociális alapszolgáltatások biztosításának küszöbét mutatja, így egyértelmủ, hogy Magyarország ezen régiójának kistérségei magukon hordozzák a kistelepülések és aprófalvak sokaságának terheit. A lakosságszám tekintetében vitatkozunk Bácskay Andreával (2005), mert bár a régióban jószerével alig található város városi funkcióval - 2008-ban mindössze 29 város volt a 626 község mellett -, mégis városban lakik a lakosság nagyobb része és nem a kistelepüléseken. A funkcionális városhiány a kistérségek önkormányzati szerveződéseit is alapvetően befolyásolta és befolyásolja ma is, a többcélú kistérségi társulások központjai ma ugyan többségében városok, de városi funkcióhiánnyal. 
Peisser-Puli Edit : Szociális alapszükségletek mérése Magyarország rurális kistérségeiben. Tér és Társadalom 23. évf. 2009/1. 79-99. p.

TÉT XXIII. évf. 2009 a 1

Gyors ténykép

93

\section{5. ÁBRA}

A kistérségek átlagnépessége és az aprófalvak aránya, 2004

(The Average Population of Sub-regions and the Proportion of Small Villages, 2004)

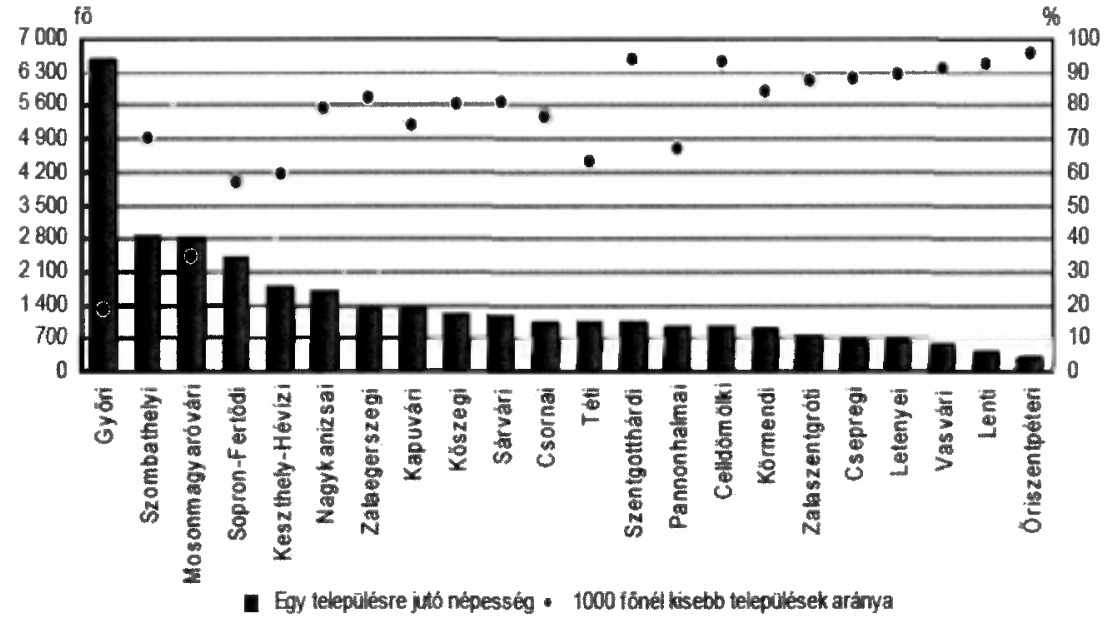

Forrás: KSH Györi Igazgatósága (2006).

Az egy településre jutó népesség és az 1000 fỏnél kisebb települések aránya a mintába került 9 kistérségben jól láthatóan, fordítottan arányosan rajzolódik ki (5. ábra). Minél kisebb a kistérségek településeinek népessége, annál inkább jellemzỏ az aprófalvas település-szerkezet, így a települési ơnkormányzatok társulási kényszere is egyre fokozottabb lehet, hiszen e nélkül alapszolgáltatásokat biztosítani nem tudnának. Ezzel párhuzamosan a rurális jelzỏ is alátámasztást nyer, hiszen az alacsony települési népességszám logikusan hozza magával a népsúrủség alacsony szintjét: 2001 és 2008 között szinte alig változtak ezek az értékek, a régióban ma átlagosan 88, Győr-Moson-Sopronban 106, Vasban 78, míg Zalában 77 fơ él egy négyzetkilométeren.

Öregedési index - a születéskor várható átlagos élettartammal és a 65 éven felüliek számával

„A társadalmi-demográfiai változások - a népesség fokozatos elöregedése, (...) a család gondozási erőforrásainak megcsappanása - következtében az idősek szociális ellátásában is egyre inkább elötérbe kerulnek az intézményes formák, (...) de fontos szerep jut a szociális alapszolgáltatásoknak is. Ide többek között az étkeztetés, a házi gondozás, a jelzőrendszeres házi segítségnyújtás (...) sorolódik, amelyek segítségével az arra rászorulók önálló életvitelüket saját otthonukban és lakókörnyezetükben fenntarthatják. Az étkeztetés és a házi segítségnyújtás elsősorban az idős lakosság támogatását szolgálja, az ellátottak döntő többsége 60 éves vagy idósebb." (Társadalmi... 2007, 60) 
Peisser-Puli Edit : Szociális alapszükségletek mérése Magyarország rurális kistérségeiben.

Tér és Társadalom 23. évf. 2009/1. 79-99. p.

94 Gyors ténykép

TÉT XXIII. évf. 2009

\section{TÁBLÁZAT}

Öregedési index és társmutatói, 2001-2007

(The Index of Ageing and its Supplementary Indicators, 2001-2007)

\begin{tabular}{|c|c|c|c|c|c|c|c|c|}
\hline \multirow[t]{2}{*}{$\begin{array}{l}\text { Települési } \\
\text { egység }\end{array}$} & \multicolumn{2}{|c|}{$\begin{array}{l}\text { Öregedési } \\
\text { index }\end{array}$} & \multicolumn{2}{|c|}{$\begin{array}{c}\text { Születéskor } \\
\text { várható élet- } \\
\text { tartam } \\
\text { Nö }\end{array}$} & \multicolumn{2}{|c|}{$\begin{array}{c}\text { Születéskor } \\
\text { várható élet- } \\
\text { tartam } \\
\text { Férfi }\end{array}$} & \multicolumn{2}{|c|}{$\begin{array}{c}65 \text { éven } \\
\text { felüliek } \\
\text { száma }\end{array}$} \\
\hline & 2001 & 2007 & $\begin{array}{l}2001 \\
(e ́ v)\end{array}$ & $\begin{array}{l}2007 \\
(e ́ v)\end{array}$ & $\begin{array}{c}2001 \\
(e ́ v)\end{array}$ & $\begin{array}{l}2007 \\
(e ́ v)\end{array}$ & $\begin{array}{c}2001 \\
(f o ́)\end{array}$ & $\begin{array}{c}2007 \\
(f o ̈)\end{array}$ \\
\hline $\begin{array}{l}\text { Györ- } \\
\text { Moson- } \\
\text { Sopron } \\
\text { megye }\end{array}$ & 91,2 & 105,3 & 78,04 & 78,08 & 69,48 & 70,25 & 63176 & 67278 \\
\hline $\begin{array}{l}\text { Vas } \\
\text { megye }\end{array}$ & 94,4 & 115,6 & 77,12 & 77,67 & 68,84 & 69,20 & 41020 & 42199 \\
\hline $\begin{array}{l}\text { Zala } \\
\text { megye }\end{array}$ & 102,1 & 130,1 & 76,83 & 78,41 & 68,24 & 69,64 & 47963 & 49992 \\
\hline Ország & 91,3 & 107,6 & 76,46 & 77,34 & 68,15 & 69,19 & 1544980 & 1605118 \\
\hline
\end{tabular}

Forrás: KSH (2007) alapján saját számítás.

Tekintettel a fenti idézetben foglaltakra, az étkeztetés és a házi segítségnyújtás szociális alapszükségletének méréséhez az öregedési index ${ }^{9}$ mutatót kiegészítettük két mutatóval (4. táblázat), amelyek az elöbbit erösítik meg, illetve a változások érzékeltetése miatt 2001 és 2007 közötti időszakra számítottuk a mutatókat. Látható, hogy a régió két megyéjének öregedési indexe 2001-ben az országos átlag körül alakult, és mind az évtized elején, mind a végén Zala megyében jut a legtöbb idős 100 gyermekkorúra. A születéskor várható átlagos élettartam mindhárom megyében magasabb az országos átlagnál, a 65 éven felüliek száma pedig ahhoz közeli arányban nö.

A három mutató együttesen az időskorú népesség számának és arányának növekedését írja le, ami a szociális alapszükségletek létét és prognosztizált növekedését mutatja. Ha ehhez hozzátesszük a település-szerkezetböl adódó aprófalvas helyzetet, ahol az idősek aránya fokozottabban nö, és ezért a falvak elfogyása rohamos léptékü, a szociális alapszolgáltatások biztositása és a szükségletek mérése rendkívül fontos lenne. „A törpefalvak lakossága rendkívül elöregedett. 2003-ban 100 aktív korú lakosra 33 időskorú jutott, a (Vas) megyei átlagnál 11-gyel több, (...) tíz településen háromszor annyi idöskorú élt, mint ahány gyermek, (...) Daraboshegyen pedig hétszer (!) annyi." (Cserta-Novák-Vörös 2004, 142) Kistérségi bontásban önmagában az öregedési index a következőképpen jelzi a szükségletek növekedését (6. ábra), különösen a minta 9 kistérségében ahol ,(...) a leghátrányosabb helyzetüek évek óta a régió délebbre fekvő aprófalvas kistérségei, amelyekben ennél (a régió 106-os értékénél) 20-60 fövel több idős ember jutott 100 gyermekkorúra, ezáltal csak a felzárkózásra van esélyük." (A kistérségek... 2006, 18) 
Peisser-Puli Edit : Szociális alapszükségletek mérése Magyarország rurális kistérségeiben. Tér és Társadalom 23. évf. 2009/1. 79-99. p.

TÉT XXIII. évf. 2009 - 1

Gyors ténykép

95

\section{6. ÁBRA}

Öregedési index, 2000-2005

(Aging index, 2000-2005)

Öregedési index

(100 gyermekkorúra jutó időskorú)

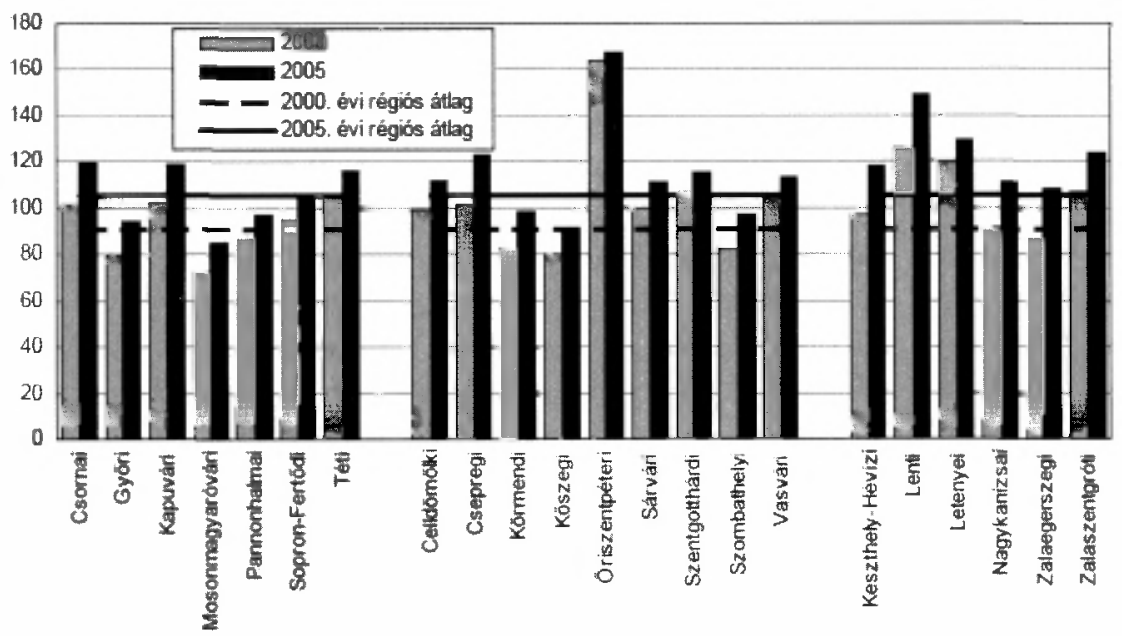

Forrás: KSH Győri Igazgatósága (2006).

Nyugdijban és nyugdijszerü ellátásban részesülök száma és a kistérségi átlagnyugdij

Ez a két mutató a szociális szükségletek szempontjából azért fontos, mert jelzi a szolgáltatások téritési dijj-fizetésének nehézségeit és az önellátás korlátait is, jövedelmi szempontból. A rászorultság elvének alkalmazása a gyakorlatban elöször a jövedelmi feltételeket jelentette, ma már a házi segítségnyújtás esetében az ápolásigondozási szükségletet is ${ }^{10}$. 2007-ben Győr-Moson-Sopron megyében 122242 fö, Vasban 75751 fó, Zalában pedig 82156 fö részesült saját jogú nyugellátásban vagy nyugdíjszerủ ellátásban. Az öregségi nyugdiji ${ }^{11}$ átlagos összege 75 465, 73147 illetve $73248 \mathrm{Ft}$ volt, ami az országos átlaghoz képest alacsonynak mondható $(78577 \mathrm{Ft})$, és mindenképpen jelzi a rászorultságot.

A ,szociális igények" adatai

Az összefoglaló adatok szerint az országban 2000-ben 40292 fó részesült házi segítségnyújtásban, míg 2006-ban már 48088 fỏ. Étkeztetésben ugyanezen években 98 158, illetve 108938 fỏ részesült, mindkét tendencia egyértelmủen növekedést mutat - mint ahogyan azt a tanulmány elején az Állami Számvevőszék jelentése alapján (Berényi et al 2007) megállapítottuk. E javulást már 2004-ben kiemelte a $\mathrm{KSH}$ : „Az étkeztetés a legelterjedtebb és jelentősen javuló arányokat mutató szemé- 
lyes gondoskodást nyújtó ellátási forma. Az egy évvel ezelöttihez képest 112-vel több településen, az összes település háromnegyedén a népesség $93 \%$-a számára vált elérhetôvé. A lehetőségek a kisebb falvakban kedvezőtlenebbek, az 500 fönél kevesebb lakosú törpefalvaknak csak 53\%-ában, az 1000 fönél kisebbek összességében $63 \%$-ban van étkeztetés. A területi különbségek jelentősek. (...) A házi segítségnyújtást a települések 61\%-ában szervezték meg, ez a népesség 91\%-át fedi le. Az 500 fönél kisebb települések egyharmadán, az ennél nagyobbakon folyamatosan növekvő arányban találunk ilyen szolgáltatást." (Szociális... 2004, 6)

Rendkívül optimista adatok ezek, amelyek, mint láttuk, szemben állnak a szakmai kutatások eredményeivel. Regionális viszonylatban az ellátottság az étkeztetés esetében 71,1, illetve házi segítségnyújtásnál 47,9\%-ot mutat, azaz alatta marad az országos adatoknak. 2003-as adatok alapján jellemzően az 5000 fő alatti településeken szervezték meg az étkeztetést és a házi segitségnyújtást is, tehát nem igazolódik az a tétel: miszerint minél kisebb egy település, annál nagyobb az ellátatlanság, sőt, ez fordítva igaz: étkeztetés tulajdonképpen az 5000 fönél kisebb településeken van. Ehhez ráadásul szinte az egész régió lakossága hozzá is fér, 466 településen 908876 ember az 1004 328-hoz képest (Szociális... 2004). A házi segítségnyújtást ugyan kevesebben érik el (805 723 fö 2003-ban), de a szolgáltatást szervező települések aránya (314 település 2003-ban) és az elérés között érdekes kapcsolat van, mert kevesebb település több emberhez ér el. Persze minden statisztikai adat valóságtartalma annyit ér csak, amennyit a valóságból képes megmutatni, hiszen azt a KSH sem tagadja, hogy 2006-ban étkeztetéssel a 60 éven felüli lakosságnak csupán 5\%-át, házi segítségnyújtással mindössze 2,2\%-át sikerült elérni! (Társadalmi... 2006)

A területi szinten alaposabb, de többnyire a KSH tendenciákat megerösítő T-STAR adatbázis egy lényeges kérdést vet fel számunkra: Miért csökken az étkeztetésben és házi segítségnyújtásban részesülők száma a régió egyik megyéjében drasztikusan, ha ugyanakkor az ellátandók köre egyre bővül? Nézzük meg ehhez az 5. táblázatot!

Látható, hogy Győr-Moson-Sopron megye étkeztetési és házi segítségnyủjtási adatai egy év leforgása alatt csökkentek, utóbbi esetében drasztikusnak mondhatóan. Vas megyében lényeges e szolgáltatás szintén drasztikus növekedése, és Zala megye minden adatának javulása. Nyilván régión belüli egyenlötlenségről van szó, amely a kistérségi szintre is vonatkoztatható, de a kérdés ettól még nyitva marad. Érdekes ez a tendencia azért, mert 2004 után járunk, amikor a többcélú kistérségi társulásos együttmúködések lehetőséget adtak az önkormányzatoknak szolgáltatásaik fejlesztéséhez, ezáltal az ellátottak számának növeléséhez. Nem érzékelhető ez az egyébként is „csak” lehetőséget adó javulás az adatok alapján. Nagyon valószínü, hogy nem a szükségletek csökkentek, hiszen azokat a citált adatok szinte teljes körủen felerősítik. 
Peisser-Puli Edit : Szociális alapszükségletek mérése Magyarország rurális kistérségeiben. Tér és Társadalom 23. évf. 2009/1. 79-99. p.

TÉT XXIII. évf. 2009

Gyors ténykép 97

\section{TÁBLÁZAT}

Étkeztetésben, házi segitségnyújtásban és mindkét szolgáltatásban részesülök száma, 2005-2006

(The Number of People Receiving Catering, Home Assistance and Both in 2005-2006)

\begin{tabular}{|c|c|c|c|c|c|c|}
\hline \multirow[t]{2}{*}{$\begin{array}{l}\text { Területi } \\
\text { egység }\end{array}$} & \multicolumn{2}{|c|}{$\begin{array}{l}\text { Étkeztetésben } \\
\text { részesülök } \\
\text { száma } \\
\end{array}$} & \multicolumn{2}{|c|}{$\begin{array}{c}\text { Házi } \\
\text { segítségnyújtásban } \\
\text { részesülök száma }\end{array}$} & \multicolumn{2}{|c|}{$\begin{array}{c}\text { Mindkét } \\
\text { szolgáltatásban } \\
\text { részesülók száma }\end{array}$} \\
\hline & 2005 & 2006 & 2005 & 2006 & 2005 & 2006 \\
\hline $\begin{array}{l}\text { Győr-M.- } \\
\text { Sopron } \\
\text { megye }\end{array}$ & 3066 & 2892 & 760 & 559 & 786 & 798 \\
\hline Vas megye & 3157 & 3121 & 376 & 682 & 843 & 868 \\
\hline Zala megye & 3065 & 3336 & 542 & 784 & 784 & 801 \\
\hline Ország & 79423 & 81880 & 17851 & 21030 & 27279 & 27058 \\
\hline
\end{tabular}

Forrás: T-STAR (2006) alapjản saját szerkesztés.

\section{Összefoglalás, konkluizió}

Arra tettünk kísérletet, hogy két adatbázis feldolgozott adatainak elemzését felhasználjuk a szociális szükségletek mérésének modellezéséhez, a szakma és a döntéshozók állításainak igazolására vagy cáfolására. A kísérlet egyik eredménye egy mutató-rendszer összeállítása lett, amely képes a szociális alapszükségletek három formáját mérhetôvé tenni azáltal, hogy egymáshoz kapcsolódóan jeleníti meg és elemzi őket, másik eredménye pedig a döntéshozói állítások árnyalása lett a KSH és a T-STAR adatbázisok segítségével. A nyolc mutató alkalmas arra, hogy szükségletet írjon le, hiszen:

- a település-szerkezet elaprózottsága, az ebböl következő

- települési népességszám-csökkenés, vagy elfogyás és az ezt fokozó

- öregedési index a születéskor várható élettartammal és a 65 éven felüliek számával,

- a nyugdíjban részesülök számával és

- az átlagnyugdíjjal,

- a komplex mutatóval és

- a kedvezményezetti besorolással,

- valamint a szociális igényekkel és azok kielégítettségével alapvetően határozza meg egy térség szociális szükségleteit az étkeztetés, a házi segítségnyújtás esetében. Feltéve, ha vannak használható adatok hozzá.

Másik eredmény az eredménytelenség: a jelzőrendszeres házi segítségnyújtásról csak minimális adatot találtunk a két adatbázisban, pedig 2004 óta megszervezése már elindult, de ennél tovább nem jutottunk: „Elterjesztése (2004 óta) gyorsan haladt, 
2006-ban már több mint 15000 ember (...) otthoni életét teszi biztonságosabbá." (A kistérségek... 2006, 61)

A KSH és T-STAR adatbázisok lényegében megerősitették a döntéshozói szint megállapításait a település-szerkezetről: funkcionális városhiány, községi stagnálás, apró- és törpefalvak elfogyása; a népességröl: városi népesség többlete, kistelepülések veszélyeztetettsége, aprófalvak elöregedése; a nyugdijasokról: alacsony öregségi nyugdíj, növekvő ellátotti kör; a komplex mutatóról és a kedvezményezettségröl, illetve a szociális igényekről: ellátást biztosító települések száma, elérhetöség. A képet a T-STAR bázis árnyalta és részletezte területi szinten, kár, hogy nincsen kistérségi részletes adatbázis, csak megyei szinten érhetők el adatok. Mégis ide kapcsolódik a kérdés: ha a régión belüli egyenlőtlenségek ilyen mérvủek, és a rurális kistérségek ellátatlansága mégis kiderül, akkor miért nem keresünk megoldásokat a szükségletek mérésére és kielégitésére a társulások számára? Kutatásunkkal e kérdéskör megoldásához szeretnénk hozzájárulni.

\section{Jegyzetek}

${ }^{1}$ Tekintettel arra, hogy a többcélú kistérségi társulásokról szóló törvény csak 2004-ben lépett hatályba, nem várhatunk kidolgozott hatékonyság-vizsgálatokat, hiszen tudjuk (Szombathelyi 2003), hogy ez nem könnyü, és számos dilemmát vet fel.

${ }^{2} \mathrm{Az}$ alapellátás - alapszolgáltatás kifejezés az éppen hatályos Szociảlis törvény fogalomhasználatát mutatja. 2002-ben a törvény alapellátásnak, 2005-ben már alapszolgáltatásnak nevezi a szociális szolgáltatások elsỏ szintjét sokszor alig vagy lényegesen változó szolgáltatástartalommal. Az alapszolgáltatások körének állandó mozgása jelenti a tradicionálisan 1993-tól megfogalmazott étkeztetést, házi segítségnyújtást és családsegitést, 2002-ben az ezeket kiegészitő speciális alapszolgáltatásokat, 2005-ben viszont már tíz fajta alapszolgáltatást. Ennek előnye és hátránya folyamatos diskurzus tárgya a szociálpolitikában, hiszen minél jobban bővül a szolgáltatási kör, annál cizelláltabban válaszol a szükségletekre az ellátórendszer. Ugyanakkor minél több kötelező feladatot testál a törvényalkotó az önkormányzatokra és ehhez minél kevesebb pénzt biztosít, annál valószínủbb az ellátási hiátusok fokozódása.

${ }^{3}$ A szakma vitatkozik azon, hogy melyik kifejezést használjuk. Általánosan elfogadott a lakosságszám alapú feladattelepítés kifejezés a szakmai nyelvhasználatban, mégis a kistelepülés, kisebb település, nagyobb település szóhasználata ezzel párhuzamosan minden elemzésben megjelenik.

4

Az alapellátások teljesítésének minőségét, a lehetőségeket és a hiányok okait, az önkormányzatok multidimenzionális problémáit, a települések életkörülményeit is górcsỏ alá vette a felmérés, ebböl a számunkra releváns szükségletekre vonatkozó reflexiókat emeljük ki. Kutatásmódszertanát tekintve is témabarát a felmérés, hiszen nem csupán kérdöivvel, hanem a kistelepülések miliöjére, kommunikációs és kapcsolati aspektusaira sokkal jobban rezonáló és hatásában is praktikusabb mélyinterjúzást használta lehetőség szerint minden településen minden olyan települési aktorral, akinek kompetenciája a szolgáltatások tervezése és szervezése terén elengedhetetlen.

${ }^{5}$ Magyarországon 1998-ban fogadták el országgyülési határozattal a 7 statisztikai-tervezési régiót. A Nyugat-dunántúli régió Győr-Moson-Sopron, Vas és Zala megyéket foglalja magában. Kiterjedése észak-déli irányban hosszan elnyúló. A régió $11183 \mathrm{~km}^{2}$-es területével az ország területének $12 \%$-át teszi ki. A Nyugat-Dunántúl természetföldrajza rendkívül változatos képet mutat. Területén három nagytáj húzódik: a Kisalföld, az Alpokalja és a Dunántúli-dombság egy része, kiegészülve a Dunántúli Középhegység északi és nyugati peremvidékeivel. A változatos felszinủ tajj vízfolyásokban és természetes, illetve mesterséges állóvizekben gazdag. A természeti rendszereket ezért viszonylagos épség jellemzi. A magas biodiverzitás megörzése mind környezeti, mind gazdasági (turizmus), mind társadalmi (életminőség) szempontból fontos.

(http://www.westpa.hu/cgi-bin/westpa/news.cgi?view=ck\&tID=89\&nID=2585)

${ }^{6}$ 2008-ban megváltozott Zala megye kistérségi rendszere a törvényi szabályozás, 2004 óta. A Zalaegerszegi kistérségtől a Pacsai, a Keszthely-hévízi kistérségtől a Hévízi, a Nagykanizsai kistérségtől a 
Peisser-Puli Edit : Szociális alapszükségletek mérése Magyarország rurális kistérségeiben. Tér és Társadalom 23. évf. 2009/1. 79-99. p.

Zalakarosi kistérség vált külön, ami hárommal növelte meg a régió kistérségeinek számát. Az új kistérségek vidékies-városias besorolásáról még nincs adat.

${ }^{7}$ A megye a magyar közigazgatási struktúra fekete báránya, jelenleg köztes közigazgatási állomás a régió és a kistérség között, hatáskörétől, feladataitól és pénzforrásaitól megfosztott intézményfenntartó szint, képlékeny jövőorientációval. Kistérségi pontosságú adatok a KSH adatbázisában nem mindig találhatók meg, ezekben az esetekben a megyei adatokból következtethetünk tovább a kistérségi helyzetre, illetve kiegészitö adatforrásokkal pontosithatjuk azokat.

9

900 gyermekkorúra (0-14 évesek) jutó időskorúak (65 éves és a felettiek) száma.

${ }^{10}$ Ennek részletes kifejtését a tanulmány keretei nem engedik meg, röviden a napi 4 óránál több ápolástgondozást jelenti, amennyiben ezt a szükséglet meghaladja, a szakosított (intézményes) ellátás felé tereli a szabályozás és az ellátórendszer a rászorulót.

${ }^{11}$ Magyarországon a nyugdíjasok túlnyomó része saját jogú öregségi nyugdíjas.

\section{Irodalom}

Bácskay A. (2005) Gondozási formák az idősellátásban - a szociális alapellátás. -Kapocs. 6. 32-48. o.

Berényi M.-Huberné Kuncsik Zs.-Valu T. (2007) Jelentés az önkormányzatok szociális alaptevékenységének ellenörzéséröl. Állami Számvevőszék, Budapest.

Cserta O.-Novák Z.-Vörös L. (2004) A Vas megyei törpefalvak sajátosságai és lehetőségei. - Területi statisztika. 2. 137-151. o.

Ferge Zs. (2005) Ellenálló egyenlōtlenségek. A mai egyenlőtlenségek természetrajzához. Akadémiai székfoglaló. - Esély 4. 3. o.

Hodosán R. (2003) Alapellátási kötelezettségek - kistelepülési stratégiák. - Kapocs. 2. 2-8. o.

A kistérségek társadalmi-gazdasági helyzete. (2006) Központi Statisztikai Hivatal Györi Igazgatósága, Gyór.

Papházi T. (2002) Kistelepülések szociális ellátó tevékenységéről statisztikai adatok alapján. - Kapocs. 3. 16-29. o.

Szociális statisztikai közlemények. Alapinformációk a települési önkormányzatok szociális tevékenységéröl 2002-2003. (2004) Központi Statisztikai Hivatal, Budapest.

Szombathelyi Sz. (2003) A szociális ellátások hatékonysági vizsgálatának dilemmái. - Kapocs. 3. 20-25. o.

Szörényiné Kukorelli I. (2006) Ruralitás, kistérségek a tizenöt éves átmenetben (társadalomföldrajzi módszerek és elemzések a magyar rurális térségekben). Doktori értekezés. Magyar Tudományos Akadémia, Győr.

Társadalmi ellátórendszerek 2006. (2007) Központi Statisztikai Hivatal, Budapest.

Többszörösen módosított 1993. évi III. törvény a szociális igazgatásról és a szociális ellátásokról.

67/2007. (VI. 28.) Országgyúlési határozat 3. sz. melléklete. 